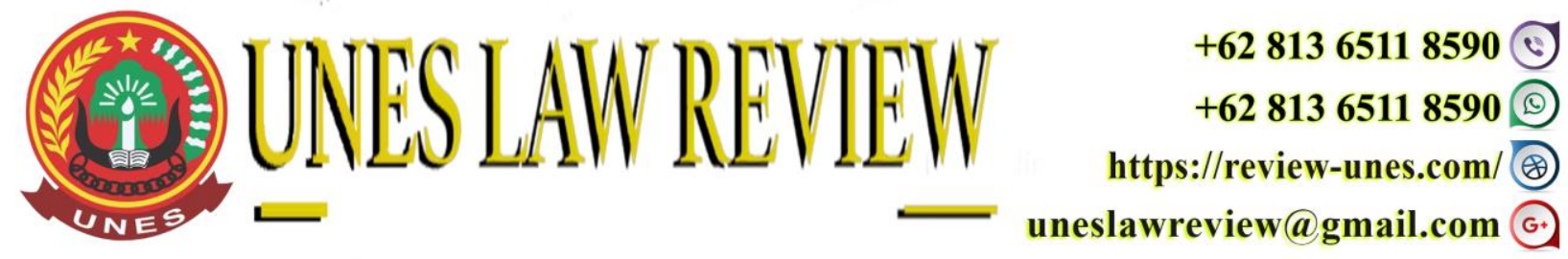

DOI: https://doi.org/10.31933/unesrev.v4i1

Diterima: 24/09/2021, Diperbaiki: 07/10/2021, Diterbitkan: 10/10/2021

\title{
KEPASTIAN HUKUM TERHADAP PEMEGANG HAK MILIK DALAM PENERBITAN SERTIPIKAT TANAH GANDA PADA SATU BIDANG TANAH
}

\author{
Lulu Fitriani $^{1}$, Muhammad Sofyan Pulungan ${ }^{2}$, Isyana Wisnuwardhani Sadjarwo ${ }^{3}$ \\ 1) Mahasiswa Magister Kenotariatan Fakultas Hukum, Universitas Indonesia, Depok, Indonesia. \\ Email: lulufitrianii@gmail.com \\ 2) Dosen Fakultas Hukum Universitas Indonesia, Depok, Indonesia. \\ Email: pulunganmsofyan @ gmail.com \\ 3) Dosen Program Magister Kenotariatan Fakultas Hukum Universitas Indonesia, Depok, Indonesia.
}

Corresponding Author: Lulu Fitriani ${ }^{1}$

\section{ABSTRACT}

Certificate of land ownership regulated in the Undang-Undang Pokok Agraria ("UUPA") is an ownership proof of the land right where it becomes powerful evidence. The increasement of necessity of a land is not followed by the increasement of the availability of land that can be utilized by the society, which causes many disputes related to the ownership or land right. One of many problems that arises is double certificate on a land. Double certificate on a land causing risks on the owner of land right where such phenomena caused by the maladministration to criminal action. Badan Pertanahan Nasional ("BPN") as an institution established by the Government that holds the sole authority in national land should be responsible in the matters related to the land dispute, especially double certificate. Beside that, there is a necessity on the legal protection to be provided by the State for the owner of land right to protect the rights of the land owner. The research performed using juridical normative with legislation approach and conseptual approach. Research result will be written in the form of explanatory-analysis where the writer explains the case in the case of lawsuit and the theories related with the problem, then analyzes the consistency between the problem and the applicable laws and regulations or theories.

Keywords: Land Dispute, Double Certificate, Legal Protection.

\section{ABSTRAK}

Sertipikat hak atas tanah yang diatur di dalam Undang-undang Pokok Agraria ("UUPA") merupakan bukti kepemilikan hak atas tanah dan menjadi suatu alat bukti yang kuat. Seiring dengan meningkatnya kebutuhan masyarakat terhadap tanah yang tidak diimbangi dengan 
pertumbuhan tanah yang dapat digunakan oleh masyarakat, mengakibatkan banyaknya sengketa terkait dengan kepemilikan hak atas tanah. Salah satu permasalahan yang banyak terjadi adalah mengenai sertipikat ganda atas sebidang tanah atau sebagian dari beberapa bidang tanah. Munculnya sertipikat ganda menjadi permasalahan yang mengancam setiap pemilik hak atas tanah dimana hal ini dapat disebabkan oleh maladministrasi maupun oleh perbuatan pidana. Badan Pertanahan Nasional ("BPN") sebagai lembaga yang dibentuk oleh Pemerintah yang memiliki kewenangan dalam pertanahan nasional sudah seharusnya bertanggungjawab sehubungan dengan sengketa pertanahan, khususnya terkait dengan sertipikat ganda. Di samping itu diperlukan adanya perlindungan hukum oleh Negara untuk para pemegang hak atas tanah agar para pemegang hak atas tanah tidak tercederai haknya. Bentuk penelitian ini adalah yuridis normatif dengan pendekatan undang-undang dan pendekatan konseptual. Hasil penelitian akan dituangkan dalam bentuk eksplanatoris-analitis dimana dimana penulis menjelaskan duduk perkara dalam kasus posisi dan teori-teori yang berhubungan dengan permasalahan yang ada, lalu menganalisis kesesuaian antara permasalahan yang terjadi dengan aturan atau teori yang berlaku tersebut.

Kata Kunci: Sengketa Tanah, Sertipikat Ganda, Perlindungan Hukum.

\section{PENDAHULUAN}

Tanah merupakan kebutuhan primer bagi manusia, dimana manusia membangun tempat tinggalnya di atas tanah. Dengan berkembangnya jumlah penduduk maka kebutuhan atas tanah semakin meningkat. Tanah merupakan suatu obyek sangat kompleks yang mudah menimbulkan sengketa, sengketa tersebut bisa terjadi antar individu, individu dengan badan hukum maupun antar badan hukum. Hal tersebut dikarenakan oleh meningkatnya jumlah penduduk, dimana dengan meningkatnya jumlah penduduk maka kebutuhan akan tanah pun bertambah namun kebutuhan akan tanah yang terus meningkat tidak diikuti oleh bertambahnya jumlah tanah yang ada di wilayah negara Indonesia. (Wantijk Saleh, 1987:7)

Undang-undang Dasar Negara Republik Indonesia ("UUD 1945") mengatur bahwa Negara sebagai sebuah organisasi atau badan tertinggi memiliki memiliki kewenangan untuk menguasai tanah dan dan memiliki kewajiban untuk mempergunakannya dalam menjamin kemakmuran rakyatnya sebagaimana diatur dalam Undang-undang Dasar Republik Indonesia Tahun 1945 ("UUD 1945") Pasal 33 ayat (3) yang berbunyi "Bumi dan air dan kekayaan alam yang terkandung di dalamnya dikuasai oleh Negara dan dipergunakan untuk sebesarbesar kemakmuran rakyat". (UUD 1945)

Sebagai pelaksanaan atas ketentuan UUD 1945 Pasal 33 ayat (3) tersebut di atas, maka diundangkanlah Undang-undang Nomor 5 Tahun 1960 tentang Pokok-Pokok Agraria ("UUPA"). Dalam penjelasan UUPA tersebut dikatakan bahwa hukum agraria harus 
memberikan kemungkinan akan tercapainya fungsi-fungsi yang berkenaan dengan bumi, air dan ruang angkasa serta harus sesuai pula dengan kepentingan masyarakatnya serta di samping itu, UUPA juga harus menjadi pemenuh ketentuan UUD 1945 Pasal 33 ayat (3). (UUPA Penjelasan Umum) Pada hakikatnya, tujuan dibentuknya UUPA adalah sebagai berikut:

a. Sebagai dasar pembentukan dan penyusunan hukum agraria Nasional, untuk memakmurkan dan memberi keadilan bagi Negara dan rakyat.

b. Sebagai dasar untuk mengadakan kesatuan dan menyederhanakan hukum pertanahan.

c. Sebagai dasar untuk memberikan kepastian hukum mengenai hak-hak atas tanah bagi rakyat.

Pasal 2 UUPA mengatur secara spesifik mengenai kewenangan dan kewajiban negara sesuai dengan ketentuan Pasal 33 ayat (3) UUD 1945 yang berbunyi sebagai berikut:

(1) Atas dasar ketentuan dalam Pasal 33 ayat (3) UUD 1945 dan hal-hal sebagai yang dimaksud dalam pasal 1, bumi air dan ruang angkasa, termasuk kekayaan alam yang terkandung di dalamnya itu pada tingkatan tertinggi dikuasai oleh Negara, sebagai organisasi kekuasaan seluruh rakyat.

(2) Hak menguasai dari Negara dalam ayat (1) pasal ini memberi wewenang untuk:

a. Mengatur dan menyelenggarakan peruntukan, penggunaan, persediaan dan pemeliharaan bumi, air dan ruang angkasa tersebut

b. Menentukan dan mengatur hubungan-hubungan hukum antara orang-orang dengan bumi, air dan ruang angkasa

c. Menentukan dan mengatur hubungan-hubungan hukum antara orang-orang dan perbuatan-perbuatan hukum yang mengenai bumi, air dan ruang angkasa.

(3) Wewenang yang bersumber pada hak menguasai dari negara tersebut pada ayat (2) pasal ini digunakan untuk mencapai sebesar-besar kemakmuran rakyat dalam arti kebangsaan, kesejahteraan dan kemerdekaan dalam masyarakat dan Negara hukum Indonesia yang merdeka, berdaulat adil dan Makmur.

(4) Hak menguasai dari Negara tersebut di atas pelaksanaannya dapat dikuasakan kepada daerah-daerah Swatantra dan masyarakat-masyarakat hukum adat, sekedar diperlukan dan tidak bertentangan dengan kepentingan nasional, menurut ketentuan-ketentuan Peraturan Pemerintah. (UUPA Pasal 2)

Bersama dengan diundangkannya UUPA, maka diberlakukanlah pendaftaran tanah sehingga rakyat bisa mendapatkan hak terhadap suatu bidang tanah. Hak-hak atas tanah tersebut disebutkan dalam UUPA yaitu sebagai berikut:
a. Hak milik
b. Hak guna usaha
c. Hak guna bangunan 
d. Hak pakai

e. Hak sewa

f. Hak membuka tanah

g. Hak memungut hasil hutan, serta

h. Hak-hak lain yang tidak termasuk dalam hak-hak tersebut di atas yang akan ditetapkan dengan undang-undang serta hak-hak yang sifatnya sementara sebagai yang disebutkan dalam Pasal 53.

Sehubungan dengan hak-hak atas tanah tersebut di atas, undang-undang mewajibkan para pemegang hak atas tanah untuk mendaftarkan tanahnya. Pendaftaran tanah merupakan hal yang penting dimana pendaftaran hak atas tanah merupakan proses awal dari lahirnya bukti kepemilikan hak atas tanah tersebut. (Supriadi, 2008:154) Pendaftaran atas tanah diatur dalam Pasal 19 ayat (1) UUPA yang menyatakan bahwa sebagai upaya untuk menjamin kepastian hukum, Pemerintah mengadakan pendaftaran tanah di seluruh wilayah Republik Indonesia dengan ketentuan-ketentuan yang diatur dalam Peraturan Pemerintah. Sertipikat tanah tidak pernah disebut dalam UUPA, namun dalam Pasal 19 ayat (2) huruf c, disebutkan surat bukti tanda hak. Surat bukti tanda hak tersebut oleh masyarakat sering ditafsirkan sebagai sertipikat tanah. (Muhammad Yamin Lubis, dkk, 2008:28)

Diadakannya pendaftaran tanah akan membawa akibat hukum yaitu diberikannya surat tanda bukti hak atas tanah yang lazim disebut sebagai sertipikat tanah kepada pemegang hak atas tanah yang bersangkutan yang berlaku sebagai alat pembuktian yang kuat. Sertipikat merupakan surat tanda bukti hak yang berlaku sebagai alat pembuktian yang kuat mengenai data fisik dan data yuridis yang termuat di dalamnya, sepanjang data fisik dan data yuridis tersebut sesuai dengan data yang ada dalam surat ukur dan buku tanah hak yang bersangkutan. Salah satu hak atas tanah yang diberikan kepada seseorang sebagai akibat dari pendaftaran tanah tersebut adalah hak milik. Hak milik adalah hal turun temurun, yang terkuat dan terpenuh, yang dapat dipunyai oleh seseorang atas tanahnya. Hak milik ini dapat beralih dan dialihkan kepada pihak lain, dan hanya boleh dimiliki oleh warga Negara Indonesia (WNI). Sedangkan Warga Negara Asing (WNA) hanya berhak memperoleh Hak milik karena pewarisan tanpa wasiat atau pencampuran harta karena perkawinan. (Kian Gunawan, 2008:12) 
Bersamaan dengan berjalannya waktu, kebutuhan akan tanah semakin bertambah, oleh karena itu pendaftaran tanah semakin banyak dilakukan oleh masyarakat. Bersamaan dengan hal tersebut tidak jarang terjadi kesalahan dalam pendaftaran hak atas tanah yang menyebabkan adanya sertipikat ganda atas sebuah bidang tanah. Fenomena sertipikat ganda tersebut disebabkan oleh berbagai macam hal termasuk, namun tidak terbatas pada bencana alam, kesalahan dalam pencatatan, serta tindak pidana pemalsuan dalam dokumen-dokumen pendaftaran tanah. Oleh sebab itu muncul pertanyaan terkait perlindungan hukum apa yang dimiliki oleh masyarakat sebagai bentuk kepastian hukum yang melindungi kepentingan dan hak masyarakat sebagaimana ketentuan Pasal 33 ayat (3) UUD 1945 dimana Negara memiliki kewajiban untuk memakmurkan masyarakat yang timbul bersamaan dengan kewenangan negara untuk menguasai tanah di Republik Indonesia.

Diterbitkannya sertipikat tanah merupakan tanda bukti kuat kepemilikan hak atas suatu tanah yang dikeluarkan oleh Badan Pertanahan Nasional ("BPN") sesuai dengan ketentuan Peraturan Perundang-undangan. Berdasarkan statistik pada website Kementrerian Agraria dan Tata Ruang/Badan Pertanahan Nasional hingga hari ini jumlah sertipikat tanah yang dikeluarkan oleh BPN adalah sejumlah 71.591.014. (Badan Pertanahan Nasional, 2020) Dapat kita ketahui bahwa dengan jumlah sertipikat yang sangat banyak yang telah dikeluarkan oleh BPN, sangat mungkin terjadi kesalahan berupa adanya sertipikat ganda atas sebidang tanah dimana kedua sertipikat tersebut adalah asli. Satu dari sekian konflik tanah yang peling sering terjadi adalah kasus tumpang tindih sertipikat di satu lahan, terkadang dua sertipikat bahkan sampai tiga atau lebih sertipikat.

Berdasarkan yang telah Penulis uraikan di atas, penelitian ini akan mengangkat pokok permasalahan sebagai berikut:

1. Bagaimanakah pertanggungjawaban Badan Pertanahan Nasional (BPN) sebagai instansi yang menerbitkan sertipikat terhadap pemegang hak milik atas adanya sertipikat ganda pada satu bidang tanah yang sama?

2. Bagaimanakah perlindungan hukum terhadap pemegang hak milik atas sertipikat tanah ganda?

\section{METODE PENELITIAN}

Penelitian ini merupakan bentuk penelitian yuridis normatif yang tidak hanya berupa deskripsi, sistematis dan dalam hal tertentu eksplanasi hukum positif tetapi juga adanya teori 
hukum yang berfungsi menjelaskan hukum. Adapun maksud penggunaan metode pendekatan yuridis normatif dalam penelitian ini adalah disamping meneliti bahan-bahan pustaka yang ada juga melihat kasus-kasus yang berkembang di masyarakat sebagai bahan pelengkap.

Oleh karena penelitian ini yuridis normatif, maka sumber dan jenis datanya berfokus pada data sekunder. Data sekunder untuk mencari landasan teori yang diperoleh dari kepustakaan yang akan digunakan sebagai bahan hukum dari penelitian. (Sri Mamudji, dkk, 2005:68). Adapun data sekunder merupakan data yang diperoleh melalui penelitian kepustakaan dimana data tersebut terdiri atas bahan hukum primer, bahan hukum sekunder dan bahan hukum tersier. (Johny Ibrahim, 2005:47)

Analisis data dalam penelitian ini, menggunakan pendekatan kualitatif yaitu analisis yang didasarkan pada pemahaman persepsi dan pemikiran sistematis penulis terhadap data yang diperoleh. Menganalisis data dalam bentuk kalimat yang memberikan uraian terhadap pelaksanaan hukum sehingga dapat dinilai berdasarkan peraturan perundang-undangan, teori atau pendapat ahli dan logika hukum sehingga dapat ditarik kesimpulan yang sangat logis yang merupakan jawaban dari permasalahan yang diteliti.

Pada tahapan terakhir dalam melakukan suatu penelitian yaitu dengan membuat laporan ilmiah atas hasil yang diperoleh dari penelitian tersebut. Adapun berdasarkan tipologi penelitian yang digunakan dalam penelitian ini berbentuk penelitian eksplanatoris, maka bentuk hasil penelitian dapat berupa laporan hasil penelitian eksplanatoris analitis.

\section{HASIL DAN PEMBAHASAN}

\section{Pertanggungjawaban Badan Pertanahan Nasional (BPN) Terhadap Timbulnya Sertipikat Ganda Atas Satu Bidang Tanah Yang Sama}

Salah satu prinsip negara hukum adalah adanya jaminan kepastian hukum, dan perlindungan hukum dimana hak-hak warga negara harus dilindungi dan dijamin oleh Negara. Sehubungan dengan hal tersebut, UUD 1945 mengatur bahwa Negara sebagai sebuah organisasi atau badan tertinggi yang berwenang untuk mengatur segala hal yang berkenaan dengan kepentingan dan kesejahteraan masyarakat luas menguasai bumi, air dan kekayaan alam yang terkandung di dalamnya dan mempergunakannya untuk sebesar-besar kemakmuran rakyat. 
Sejak zaman dahulu tanah telah menjadi sumber sengketa bagi manusia karena jumlahnya yang terbatas sehingga menimbulkan perebutan terhadap hak atas tanah yang memicu terjadinya sengketa tanah yang berkepanjangan, bahkan pemilik tanah rela berkorban apa saja untuk mempertahankan tanah yang dimilikinya. Mochammad Tahud menyatakan sebagai berikut:

"Soal agraria (soal tanah) adalah soal hidup dan penghidupan manusia, karena tanah adalah asal dan sumber makanan bagi manusia. Perebutan terhadap tanah berarti perebutan makanan, tiang hidup manusia. Untuk itu orang rela menumpahkan darah mengorbankan sebala yang ada demi mempertahankan hidup selanjutnya". (Mochammad Tauhid, 2009:3)

Konflik yang berhubungan dengan tanah senantiasa berlangsung secara terus menerus, karena setiap orang pasti memiliki kepentingan yang berkaitan dengan tanah. Faktor penyebab utama munculnya konflik tanah adalah luas tanah yang tetap, sementara jumlah manusia yang memerlukan tanah untuk memenuhi kebutuhannya selalu bertambah. (Maria S.W, 2009:11) Pada dasarnya sumber konflik pertanahan sekarang ini sering terjadi disebabkan antara lain oleh:

1. Pemilikan/penguasaan tanah yang tidak seimbang dan tidak merata;

2. ketidakserasian penggunaan tanah pertanian dan non pertanian;

3. Kurangnya keberpihakan kepada masyarakat golongan ekonomi lemah;

4. Kurangnya pengakuan terhadap hak-hak masyarakat hukum adat atas tanah (hak ulayat);

5. Lemahnya posisi masyarakat pemegang hak atas tanah dalam pembebasan tanah;

6. Permasalahan pertanahan dalam penerbitan sertifikat yang antara lain:

a. Proses penerbitan sertifikat tanah yang lama dan mahal,

b. Sertifikat palsu,

c. Sertifikat tumpang tindih (overlapping),

d. Pembatalan sertifikat. (Lutfi I Nasoetion, 2002:112)

Oleh karena tanah merupakan suatu objek yang mudah menimbulkan sengketa sehingga

karena mudahnya timbul sengketa atas tanah, diaturlah mengenai pendaftaran tanah dalam UUPA. Berdasarkan Peraturan Pemerintah Nomor 24 Tahun 1997, pendaftaran tanah adalah:

"rangkaian kegiatan yang dilakukan oleh Pemerintah secara terus menerus, berkesinambungan dan teratur, melputi pengumpulan, pengolahan, pembukuan, dan penyajian serta pemeliharaan data fisik dan data yuridis, dalam bentuk peta dan daftar, mengenai bidang-bidang tanah dan satuan-satuan rumah susun, termasuk pemeberian surat tanda bukti haknya bagi bidang-bidang tanah yang sudah ada haknya dan hak milik satuan rumah susun serta hak-hak tertentu yang sudah dada haknya dan hak milik atas satuan rumah susun serta hak-hak tertentu yang membebaninya".

Pendaftaran tanah diwajibkan kepada pemegang hak untuk mendaftarkan masing-masing tanahnya. Pendaftaran tanah merupakan persoalan yang sangat penting dalam UUPA karena 
pendaftaran tanah merupakan awal dai proses lahirnya sebuah bukti kepemilikan hak atas tanah. (Supriadi, 2008: 154)

Pendaftaran tanah diselenggarakan di seluruh wilayah Republik Indonesia menurut ketentuan-ketentuan yang diatur dengan Peraturan Pemerintah untuk menjamin kepastian hukum. Atas pendaftaran tanah tersebut meliputi:

1. Pengukuran perpetaan dan pembukuan tanah;

2. Pendaftaran hak-hak atas tanah dan peralihan hak-hak tersebut;

3. Pemberian surat-surat tanda bukti hak, yang berlaku sebagai alat pembuktian yang kuat. Tertib administrasi pertanahan merupakan target dari usaha memperoleh kepastian hukum dan kepastian hak atas tanah dan UUPA telah meletakkan kewajiban pada pemerintah untuk melaksanakan pendaftaran tanah-tanah yang ada di seluruh Indonesia disamping bagi para pemegang hak untuk mendaftar hak atas tanah yang ada padanya sesuai dengan ketentuan yang berlaku. Pendaftaran tanah sangat penting bagi pemegang hak atas tanah, demi terjaminnnya kepastian hukum hak atas tanah yang bersangkutan, sehingga dengan mudah dapat mengetahui status atau kedudukan hukum tanah tersebut. Pendaftaran tanah dimaksud adalah dengan meminta kepada kantor pertanahan agar tanah yang dimiliki atau dikuasai oleh seseorang atau badan hukum dicatat identitasnya di kantor pertanahan dan kepada pemegang hak yang sah diberikan sertipikat tanah.

Permasalahan mengenai tanah kini telah mengalami perkembangan melalui sifat dan substansi kasus sengketa pertanahan yang tidak lagi hanya melalui hukum administrasi, namun juga telah merambah ke lingkup politik, sosial, budaya dan terkait dengan persoalann nasionalisme dan hak asasi manusia. (Eko Yulian Isnur, 2012:47) Penertbitan sertipikat sebagai bukti atas kepemilikan hak atas tanah dimaksudkan untuk menjaga kepentingan pihak yang memiliki hak atas tanah tersebut, namun seiring dengan pertumbuhannya, pendaftaran tanah pihak yang merasa dirugikan atas kesalahan dalam pendaftaran tanah juga semakin banyak. Pasal 1 ayat (2) Peraturan Menteri Agraria Dan Tata Ruang/Kepala Badan Pertanahan Nasional Nomor 11 Tahun 2016 tentang Penyelesaian Kasus Pertanahan ("Permen Agraria 11/2016") menjelaskan bahwa yang dimaksud dengan sengketa tanah adalah perselisihan pertanahan antara perseorangan, badan hukum, atau lembagta yang tidak berdampak luas. Salah satu permasalahan dalam hal pertanahan adalah sering munculnya sertifikat ganda yang tentunya mengakibatkan kerugian kepada pembeli tanah. 
Terdapat beberapa faktor yang mengakibatkan timbulnya persengketaan tanah mengenai sertifikat ganda, yaitu sebagai berikut:

a. Sertifikat ganda dapat terjadi karena adanya kekeliruan sebagai berikut:

(1) Pada saat dilaksanakannya pengukuran, pemohon dengan sengaja atau tidak sengaja menunjukkan letak tanah dan batas tanah yang salah.

(2) Adanya surat bukti atau pengakuan hak dibelakang hari yang terbukti tidak benar, palsu atau sudah tidak berlaku.

(3) Wilayah yang bersangkutan belum tersedia peta pendaftaran tanahnya.

(4) Kasus penerbitan lebih dari satu sertifikat dapat pula terjadi karena adanya pewarisan terhadap tanah tersebut. Kasus ini banyak dilatar belakangi oleh sengketa harta warisan yaitu oleh pemilik sebelum diwariskannya tanah tersebut, tenah tersebut telah dijual kepada pihak lain tanpa sepengatuan ahli warisnya dan telah diterbitkan sertifikat atas nama pembeli, kemudian para ahli waris yang tidak mengetahui jual beli tersebut melakukan pendaftaran sehubungan dengan perubahan kepemilikan hak tersebut menjadi atas nama para ahli warisnya, sehingga terjadi sertifikat ganda yang juga disebabkan oleh sertifikat terdahulunya ternyata belum dipetakan.

b. Terjadinya sertifikat ganda sebagai salah satu akibat adanya tumpang tindih dalam penerbitan sertifikat hak atas tanah yang disebut cacat hukum administrasi.

Sertifikat hak atas yang cacat hukum administratif adalah sertifikat hak atas tanah yang mengandung kesalahan-kesalahan yang diatur dalam Pasal 107 Peraturan Menteri Agraria dan Tata Ruang/Kepala Badan Pertanahan Nasional Nomor 9 Tahun 1999 tentang Tata Cara Pemberian dan Pembatalan Hak Atas Tanah Negara Dan Hak Pengelolaan sebagai berikut:

(1) Kesalahan prosedur;

(2) Kesalahan penerapan peraturan perundang-undangan

(3) Kesalahan subjek hak;

(4) Kesalahan objek hak;

(5) Kesalahan jenis hak;

(6) Kesalahan perhitungan luas;

(7) Terdapat tumpang tindih hak atas tanah;

(8) Data yuridis dan data fisik tidak benar; atau

(9) Kesalahan lainnya yang bersifat administratif.

c. Terjadinya sertifikat ganda dipengaruhi oleh adanya faktor intern dan faktor ekstern

Terjadinya sertifikat ganda dipengaruhi oleh berbagai faktor, baik faktor internal maupun eksternal. Faktor-faktor internal yang dimaksud adalah:

(1) Tidak dilaksanakannya UUPA dan peraturan-peraturan pelaksanaannya secara bertanggungjawab serta adanya oknum-oknum yang berniat untuk mendapatkan keuntungan pribadi dalam pendaftaran tanah selain pihak yang berhak memiliki hak atas tanah tersebut. Faktor ini merupakan pengaruh yang datang dari dalam instansi Kantor Pertanahan itu sendiri.

(2) Disfungsi aparat yang berwenang dalam pengawasan sehingga mengakibatkan tersedianya peluang kepada aparat di bawahnya untuk melakukan penyelewengan dalam hal ini tidak melaksanakan tugas dan tanggung jawab sesuai dengan sumpah jabatannya. 
(3) Tidak teliti dan tidak cermatnya pejabat Kantor Pertanahan dalam penerbitan sertifikat tanah yang merupakan dokumen yang menjadi dasar penerbitan sertifikat. (Iwan Permadi, 2016:458)

Faktor eksternal yang dimaksud adalah sebagai berikut:

(1) Kurangnya pengetahuan dan pemahaman masyarakat terkait dengan undangundang dan peraturan pelaksanaan tentang pertanahan, khususnya mengenai prosedur pembuatan sertifikat tanah;

(2) Persediaan tanah tidak seimbang dengan jumlah peminat yang memerlukan tanah dan ekonomi masyarakat itu sendiri;

(3) Pembangunan mengakibatkan kebutuhan akan tanah terus meningknt, sedangkan persediaan tanah terbatas sehingga mendorong peralihan funsi tanah pertanian ke non pertanian, mengakibatkan harga tanah terus melonjak tinggi.

Berdasarkan faktor-faktor tersebut di atas, maka dapat dilihat terdapat 4 bentuk sertipikat ganda sebagai berikut:

a. Kedua atau lebih sertifikatnya asli atau salah satunya asli tapi palsu. Hal ini berarti keduanya mempunyai salinan dalam arsip Kantor Pertanahan. Hal ini dapat terjadi karena suatu bidang pertanahan yang sudah bersertifikat didaftarkan lagi pada Kantor Pertanahan. Dalam hal ini kedua sertifikat adalah sertifikat asli yang dikeluarkan oleh BPN namun obyeknya merupakan obyek yang sama, baik secara letak, posisi, maupun luasnya.

b. Kedua sertifikat adalah palsu, di mana kedua sertifikat ganda atas bidang tanah tersebut tidak tersimpan salinannya di Kantor Pertanahan.

c. Salah satu atau lebih dari sertifikat tersebut merupakan bagian dari serttifikat yang lain. Hal ini disebabkan oleh bidang tanah tersebut seharusnya didaftarkan melalui prosedur pemecahan, pemisahan atau penggabungan.

d. Overlapping atau tumpang tindih artinya terdapat dua atau lebih sertifikat tumpang tindih dengan lainnya sehingga bagian yang tumpang tindih tersebut merupakan sertifikat ganda, karena sebagian tanahnya seharusnya masuk dalam sertifikat tanah yang lainnya. (Iwan Permadi, 2016:460)

Kewenangan untuk mengeluarkan sertipikat hak atas tanah adalah milik Badan Pertanahan Nasional ("BPN") yang merupakan badan yang berwenang dalam melakukan pendaftaran hak atas tanah dan pemeliharaan daftar umum dengan pembentukan unit kerja yang dikenal dengan kantor pertanahan sebagai mana ditentukan dalam Pasal 1 ayat (22) Peraturan Pemerintah Nomor 24 Tahun 1997 tentang Pendaftaran Tanah ("PP 24/1997"). Secara lebih lanjut, mengenai Tugas BPN diatur dalam Pasal 2 Peraturan Pemerintah Nomor 10 Tahun 2006 tentang Badan Pertanahan Nasional ("PP 10/2006") yang berbunyi "Badan Pertanahan 
Nasional mempunyai tugas melaksanakan tugas pemerintahan di bidang pertanahan secara nasional, regional, dan sektoral".

Dalam pelaksanaan tugasnya, BPN memiliki fungsi sebagai berikut:

a. Perumusan kebijakan nasional di bidang pertanahan;

b. Perumusan kebijakan teknis di bidang pertanahan;

c. Koordinasi kebijakan, perencanaan dan program di bidang pertanahan;

d. Pembinaan dan pelayanan administrasi umum di bidang pertanahan;

e. Penyelenggaraan dan pelaksanaan survei, pengukuran dan pemetaan di bidang pertanahan;

f. Pelaksanaan pendaftaran tanah dalam rangka menjamin kepastian hukum;

g. Pengaturan dan penetapan hak-hak atas tanah;

h. Pelaksanaan penatagunaan tanah, reformasi agraria dan penataan wilayah-wilayah khusus;

i. Penyiapan administrasi atas tanah yang dikuasai dan/atau milik negara/daerah bekerjasama dengan Departemen Keuangan;

j. Pengawasan dan pengendalian penguasaan pemilikan tanah;

k. Kerja sama dengan Lembaga-lembaga lain;

1. Penyelenggaraan dan pelaksanaan kebijakan, perencanaan dan program di bidang pertanahan;

m. Pemberdayaan masyarakat di bidang pertanahan;

n. Pengkajian dan penanganan masalah, sengketa, perkara dan konflik di bidang pertanahan;

o. Pengkajian dan pengembangan hukum pertanahan;

p. Penelitian dan pengembangan di bidang pertanahan;

q. Pendidikan, latihan dan pengembangan sumber daya manusia di bidang pertanahan;

r. Pengelolaan data dan informasi di bidang pertanahan;

s. Pembinaan fungsional lembaga-lembaga yang berkaitan dengan bidang pertanahan;

t. Pembatalan dan penghentian hukum antara orang, dan/atau badan hukum dengan tanah sesuai dengan ketentuan peraturan perundang-undangan yang berlaku;

u. Fungsi lain di bidang pertanahan sesuai dengan peraturan perundang-undangan yang berlaku. 
Dapat dilihat pada fungsi BPN di atas, bahwa BPN merupakan badan yang memiliki kewenangan terkait dengan pendaftaran tanah dan penerbitan sertifikat hak atas tanah serta pengawasan atas kepemilikan tanah. Dalam pelaksanaannya, BPN memiliki fungsi untuk mengelola data terkait dengan tanah dan hak atas tanah tersebut. Oleh karena itu, bila terdapat kesalahan dalam administrasi atau maladministrasi sehubungan dengan pertanahan dimana di dalamnya termasuk permasalahan sertifikat ganda, maka hal tersebut adalah mutlak tanggung jawab dari BPN sebagai satu-satunya badan yang memiliki kewenangan dalam pendaftaran tanah.

Pada dasarnya, dalam rangka meminimalkan sengketa pertanahan, BPN sebagai pelayan masyarakat berperan untuk:

a. Menelaah dan mengelola data untuk menyelesaikan perkara di bidang pertanahan;

b. Menampung gugatan-gugatan, menyiapkan bahan yang berhubungan dengan berkasberkas yang diperlukan untuk persidangan atas perkara yang diajukan melalui peradilan terhadap perorangan dan badan hukum yang merugikan negara;

c. Mengumpulkan data masalah dan sengketa pertanahan;

d. Menelaah dan menyiapkan konsep keputusan mengenai penyelesaian sengketa atas tanah.

Setiap penyelenggaraan urusan pemerintahan yang di dalamnya ada unsur maladministrasi dan merugikan masyarakat, tanggung jawab dan tanggung gugatnya dibebankan kepada pribadi orang yang melakukan tindakan maladministrasi tersebut. Selain itu, jika terdapat unsur pidana dalam maladministrasi tersebut, maka Negara akan melakukan pertanggungjawaban pidana. Bila dalam maladministrasi disertai dengan perbuatan melawan hukum, maka dapat diajukan gugatan perdata atas pejabat yang melakukan tindakan maladministrasi. Dalam hal tidak terjadi maladministrasi, namun ditemukan perbuatan melawan hukum, maka ganti rugi menjadi tanggung jawab institusinya.

\section{Perlindungan Hukum Terhadap Pemilik Sertipikat Tanah Ganda}

Dalam hal terjadinya maladministrasi dibidang pertanahan yang mengakibatkan adanya sertipikat ganda pada hak atas tanah, secara umum pihak yang dirugikan adalah masyarakat luas karena adanya risiko sengketa atas tanah yang hendak didapatkan haknya. Pemegang hak atas tanah yang bersertipikat ganda yang mendapatkan hak atas tanah tersebut dengan 
itikad yang baik dan prosedur yang sesuai tentunya akan merasa dirugikan baik secara material maupun secara immaterial. Demi memberikan kepastian hukum dan perlindungan hukum terhadap pemilik hak atas tanah, maka dibuatlah peraturan-peraturan yang melindungi kepentingan para pemilik hak yang mendapatkan hak atas tanahnya dengan itikad baik dan sesuai dengan ketentuan dalam hal terjadinya sengketa terkait sertipikat tanah ganda.

Pasal 3 dan 4 PP 24/1997 menyebutkan bahwa tujuan diselenggarakannya pendaftaran tanah adalah untuk memberikan kepastian hukum dan perlindungan hukum kepada pemegang hak atas suatu bidang tanah, di mana pemegang hak dengan mudah dapat membuktikan dirinya sebagai pemilik hak atas suatu bidang tanah. Pembuktian ini dilakukan dengan pencatatan-pencatatan pada dokumen-dokumen yang menunjukkan kepemilikan hak atas tanah, di mana dalam dokumen tersebut dicantumkan pula data fisik dan data yuridisnya. Dalam hal ini, maka dapat dibuktikan siapa pemilik hak atas berdasarkan data-data yang dicatatkan pada saat pendaftaran tanah. Dalam hal terjadi sertipikat ganda, bila salah satu pihak yang memiliki sertipikat memalsukan data pada sertipikatnya, maka dapat diketahui dengan melihat pada arsip yang dimiliki oleh BPN.

Di samping itu, pada Pasal 32 ayat (2) PP 24/1997 menyatakan bahwa pihak yang merasa memiliki hak atas tanah tidak berhak lagi untuk menuntut pelaksanaan hak tersebut bila dalam jangka waktu 5 tahun sejak diterbitkan sertipikat tersebut tidak mengajukan keberatan. Hal ini memberikan kepastian pada pemegang hak bahwa setelah jangka waktu 5 tahun tanah tersebut dimiliki haknya, maka tidak ada pihak lain yang dapat melakukan upaya hukum untuk mendapatkan hak atas tanah tersebut secara paksa dari pemegang hak atas tanah tersebut.

Menurut Maria S.W. Soemardjono, cukup adil bila setelah 5 tahun lewat tanpa gugatan, pemegang sertipikat yang menguasai tanah dengan itikad baik tidak dapat digugat lagi, dan sebaliknya, bagi pemegang hak atas tanah yang sah diberi waktu 5 tahun untuk dapat menggugat pihak lain yang menguasai tanahnya dengan itikad baik dan mendaftarkannya. Tanpa adanya batasan waktu, setiap pembeli yang telah memiliki sertipikat dapat digugat oleh pihak lain. Dengan adanya batas waktu tersebut, secara tidak langsung setiap pemegang hak atas tanah yang sah didorong untuk menguasai tanahnya, menggunakannya sesuai dengan tujuan dan sifat haknya, serta mengusahakan tanda buktinya. (Maria S.W, 2001:121) 
Surat Edaran Mahkamah Agung Nomor 3 Tahun 2018 bagian 5 tentang Rumusan Hukum Kamar Tata Usaha Negara memberikan perlindungan terkait dengan sertipikat tumpang tindih. Pada poin E angka 1 disebutkan bahwa pengujian keabsahan sertipikat hak atas tanah oleh Pengadilan TUN dalam hal terdapat sertipikat tumpang tindih, hakim dapat membatalkan sertipikat yang terbit kemudian, dengan syarat sebagai berikut:

a. Pemegang sertipikat yang terbit terlebih dahulu menguasai fisik tanah dengan itikad baik; atau

b. Riwayat hak dan penguasaannya jelas dan tidak terputus; atau

c. Prosedur penerbitan sertipikat yang terlebih dahulu sesuai dengan peraturan perundang-undangan.

Dalam hal persyaratan di atas tidak terpenuhi, maka untuk masalah kepemilikan terlebih dahulu harus diselesaikan melalui proses perkara perdata di Pengadilan Negeri.

Ketentuan di atas memberikan perlindungan terhadap pemegang hak atas tanah yang mendapatkan haknya lebih dahulu selama ketentuan-ketentuan lainnya terpenuhi dengan cara membatalkan sertipikat ganda terkait hak atas tanah yang muncul dikemudian hari sehubungan suatu bidang tanah.

\section{KESIMPULAN}

BPN sebagai satu-satunya lembaga yang berwenang dalam pertanahan Nasional. BPN memiliki fungsi dari pendaftaran hak atas tanah sampai dengan pengawasan terhadap hak atas tanah. Oleh karena hal tersebut, maka bila muncul sertipikat ganda yang disebabkan oleh maladministarasi, maka BPN mutlak bertanggungjawab atas hal tersebut. BPN akan melakukan pertanggungjawaban baik secara pidana maupun perdata baik secara individu atau secara institusinya terhadap cedera yang timbul dalam masyarakat maupun pada individu.

Negara memberikan perlindungan hukum pada pemilik hak atas tanah dengan membuat Undang-undang dan Peraturan yang menjamin kepastian hukum bagi para pemilik hak atas tanah. Dengan menyelenggarakan pendaftaran tanah, maka dimulai upaya perlindungan terhadap pemilik hak atas tanah. Perlindungan hukum terhadap pemegang hak atas atas tanah tidak hanya sekedar pendaftaran tanah tapi juga dengan adanya peraturan lainnya yang mengatur bahwa tidak dapat terjadi gugat-menggugat terhadap tanah yang telah dimiliki haknya selama lebih dari 5 tahun. Hal ini memberikan hak kepada pemegang hak dengan itikad baik untuk mengajukan gugatan untuk melindungi kepentingannya terkait dengan haknya atas suatu bidang tanah, dan setelah 5 tahun, seorang pemilik hak atas tidak dapat digugat terkait dengan tanah yang dimiliki haknya, di mana hal ini menyediakan perlindungan hukum bagi pemilik hak atas tanah.

\section{DAFTAR PUSTAKA}


Gunawan, Kian. (2008). Hukum Agraria Indonesia: Himpunan Peraturan Hukum Tanah. Yogyakarta: Pustaka Grahatama.

Ibrahim, Johny. (2005). Teori dan Metode Penelitian Hukum Normatif. Cet.2. Malang: Bayu Media Publishing.

Isnur, Eko Yulian. (2012). Tata Cara Mengurus Segala Macam Surat Rumah Dan Tanah. Yogyakarta: Pustaka Yustisia.

Lubis, Mhd. Yamin dan Abd. Rahin Lubis. (2008). Hukum Pendaftaran Tanah. Jakarta: Mandar Maju.

Mamudji, Sri. et.al. (2005). Metode Penelitian dan Penulisan Hukum. Jakarta: Badan Penerbit Fakultas Hukum Universitas Indonesia.

Nasoetion, Lutfi I. (2002). Konflik Pertanahan (Agraria) Menuju Keadilan Agraria. Bandung: Yayasan AKATIGA.

Permadi, Iwan. (2016). Perlindungan Hukum Terhadap Pembeli Tanah Bersertifikat Ganda dengan Cara Itikad Baik Demi Kepastian Hukum. Malang: Yustisia Vol.5 No. 2 Mei - Agustus.

Saleh, Wantijk. (1987). Hak Anda Atas Tanah. Jakarta: Ghalia Indonesia.

Sumardjono. Maria S.W. (2001). Kebijakan Pertanahan antar Regulasi dan Implementasi. Jakarta: Kompas Media Nusantara.

Sumardjono, Maria S.W. (2009). Tanah Dalam Perspektif Hak Ekonomi Sosial dan Budaya. Jakarta Kompas.

Tauhid, Mochammad. (2009). Masalah Agraria Sebagai Masalah Penghidupan dan Kemakmuran Rakyat Indonesia. Yogyakarta: STPN Press.

Supriadi. 2008. Hukum Agraria. Jakarta: Sinar Grafika.

Indonesia. Undang-Undang Dasar 1945 LN No. 75 Tahun 1959, L,N No. 69 Tahun 1959 dan perubahannya.

- Undang-Undang Tentang Peraturan Dasar Pokok-Pokok Agraria, UU No. 5 Tahun 1960, LN Nomor 104, TLN No. 2043.

. Peraturan Pemerintah Tentang Pendaftaran Tanah, PP No. 24 tahun 1997, LN Nomor 59, TLN No. 3696.

. Peraturan Presiden Tentang Badan Pertanahan Nasional, PerPres No. 10 tahun 2006, LN Nomor 60, TLN No. 4631. 
"Statistik Kementrian Agraria dan Tata Ruang/Badan Pertanahan Nasional", https://www.atrbpn.go.id/?menu=statistik, diakses pada tanggal 7 September 2021.

Rohekan, Arief Basuki, "Sering Terjadi Tumpang Tindih Sertifikat Tanah, Ini Upaya Ikatan Notaris Indonesia Palembang", https://sumsel.tribunnews.com/2020/01/23/seringterjadi-tumpang-tindih-sertifikat-tanah-ini-upaya-ikatan-notaris-indonesiapalembang, diakses pada tanggal 7 September 2021. 